

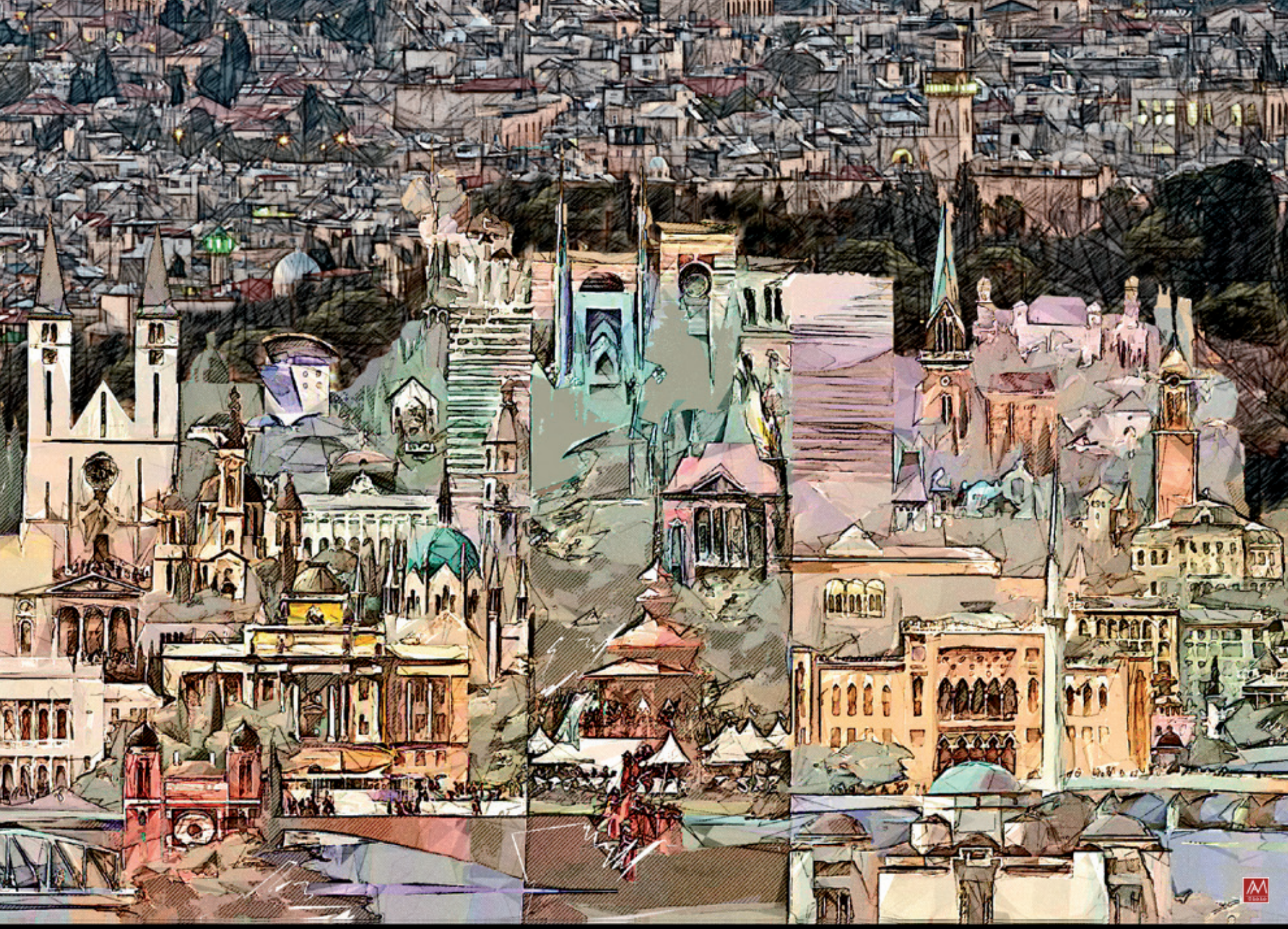

Stefan Jakob WIMMER

RELIGIJA U SEKULARNOM DRUŠTVU

Prepreka ili korist?

RELIGION IN A SECULAR SOCIETY Impediment or Benefit? 


\begin{abstract}
The author investigates from the perspective of a Western European country, in his case Germany, if and how religion(s) can be appreciated in a secular society. With historic reviews he demonstrates that we should revise our accustomed perceptions; how (in the "West") Islam is perceived, how religions are perceived from outside, but also how the religious sometimes misrepresent the non-religious. Instead, he advocates to adjust our categories of "us" and "the others", and join forces with those who are committed to living together against those who campaign and agitate against it, notwithstanding who believes in what. His considerations are shaped by the situation in Germany, but they lead to conclusions of universal value.
\end{abstract}

Key words: perspectivity of perception, Germany, Jerusalem, Christianity, Islam, secular society, secular state, irreligiousness, religious history, misuse of religion, nationalism, Enlightenment, 1968, Pope Francis. 


\section{Change in perspective}

$\mathrm{t}$ is justly fitting, when I take readers for an introduction to the topic from Sarajevo - the Jerusalem of Europe

- to Jerusalem. I was living there for seven years, when I was a student at the Hebrew University. They were seven years of abundance (cf. the Story of Josef in Genesis 41:53, and Surat Yusuf 12:47) in an intellectual and spiritual sense, as living in Jerusalem can teach those, who want to learn, a wealth on various religions and denominations, and experience how to live with each other (co-existence), aside each other (iuxta-existence), and, unfortunately too, against each other (contra-existence). For me this chapter in my biography meant living as a foreigner (German) and being part of a religious minority (Christian). ${ }^{1}$ I was curious to learn what people associated in their minds, maybe tacitly, with the notion of being Christian. So, at times I used to interview my friends and asked them, what would spontaneously come to their mind-without contemplating-when they thought about Christianity. Their answers were shaped much by the very specific situation in the Old City of Jerusalem. A very dominant perception was that of Christians being split in an incredibly complicated mélange of denominations, with a long history of rivalry and conflict among each other. Indeed, the various churches have been competing over their possessions of holy sites. The Nativity Church in Bethlehem, built over the cave where according to tradition Jesus Christ was born, is shared by Orthodox, Catholic and Armenian monks and priests, and it does occur that they clash over their alleged rights and claims, which part of the Church is whose "territorial" possession, and this can escalate even up to violent scuffles. Pictures and videos of wounded monks being carried out of the church by paramedics regularly cause prime attention in the media - and the public is being confronted with a message like "this is how religious Christians treat each other", "We know, as we read it in the newspapers, and keep seeing it in TV." Further, my friends attested Christians a strong affinity to physically touch objects considered holy, stones where Jesus purportedly walked, kiss these and especially icons. Among oriental and orthodox believers this is in fact common, while the more restrained and inward piety of many other Christians is much less eye-catching, and hence not being perceived from outside. When I inquired about the essentials of Christian faith, I was regularly told that - unlike in Islam or Judaism - it was not consistent with rationality: Christians claim Jesus to be the son of God, but also God himself. They confess monotheism, but keep addressing a trinity. And when, increasingly desperate, I tried to extract any

${ }^{1}$ Around 1990, w are less than $1.5 \%$ Christians, some $37 \%$ Muslims, and 60 \% Jews. Source:

Hen I lived in Jerusalem, Christians counted $3 \%$ of the population of Jerusalem (with some $25 \%$ Muslims and $72 \%$ Jews). Today there.

AUTUMN 2020. Volume 2, No. 2. - illuminatio/svietionik/almanar - 217 
positive perceptions of Christians, I heard no matters of faith, but compliments on the high quality education in schools established in Palestine by the missionaries of the $19^{\text {th }}$ century, on the impressive architecture of famous cathedrals in Europe, and on the wonderful music by classical composers such as Bach.

Obviously, it can be quite disillusioning, even devastating, to experience once own believe - concerns that are sacred, dear and precious to oneself - from an outside perspective. And yet, all these observations are per se true, they are neither fake news nor propaganda lies. But they have nothing to do, nothing at all, with how most ordinary Christians themselves would perceive and appreciate and (hopefully) live their own religion. After my return to Germany, I started to understand what Muslims here must be experiencing! The outside perception of Islam and Muslims, as it is constantly conveyed by media, but also, to a degree, by people's own observations, may have nothing to do, nothing at all, with how entirely normal Muslims may perceive and appreciate and (hopefully) live their own religion.

\section{Religion as seen from outside}

a fter this lengthy introduction, I would now want to transfer this change of perspective, from looking at one's own religion from outside, to perceiving religion as such from outside. Keep in mind that in a secular Western society, such as here in Germany, the non-religious view is not something odd or estranging - it is widely predominant. And it in turn considers religious views, to a certain degree at least, rather odd and of more and more marginal relevance. The mechanisms that motivate us to cherish the positive aspects of what we consider our own, while pointing out the negative on the others' side, work here as well. People who keep distant from religion tend to emphasize the tremendous amount of harm that religions are being accused of having generated in the past and up to the present. The stereotypes are well known: Religions are purportedly the direct or indirect reasons for virtually all wars, they have been sowing intolerance and segregation, resentments against science and rejection of human rights, they incite their adherents and at the same time lull them into backwardness and fatalism (cf. Karl Marx's "opium of the people"); the frequent key words in this context speak for themselves: "holy war", terror, crusades, inquisition, suppression of women, child abuse, etc. etc. Hasn't John Lennon's “Imagine no religion” been expressing for generations the very understandable desire for a better and more peaceful world?

Let us at this point review the beginnings of the two religions that concern us most. When we juxtapose Christianity and Islam, we can obviously diagnose striking differences. As a matter of fact, Islam was in its earliest stages involved in a context of violent conflicts that included fighting, wars and military expansion. From the Muslim inside view the essential perception is that initially self-defense against existential threats from outside was at stake for the very survival of the early believers; then, political power was secured, but not faith itself was spread through violence and coercion. By no means could the Prophet Muhammad himself 
have remained on the sidelines, invoking his spiritual function, but had to comprehensively lead the Ummah as its head in all regards, including the most dangerous and most unpleasing of necessities. All preference was put on preventing and avoiding violence and conflict wherever possible, and where war was inevitable, rules were set to establish that religion was not compatible with excessive and inhuman behavior in any respect. The astonishing extent of the speedy expansion of the first Islamic empire may be seen as expectable in view of religious enthusiasm. But it is stressed that the other religions, now under Muslim governance, such as Christianity, Judaism, Zoroastrism, were respected and no mass conversions to Islam enforced.

Early Christians were confronted with most severe persecutions by the powerful and relentless Roman Empire for the first three hundred years of the Christian era. They survived without resisting in any violent way. Apparently, it was their resolute and unconditional readiness for martyrdom - in the sense of being killed for not fighting, not being killed as fighters, which they considered incompatible and even contrary to Jesus' message -, which so profoundly impressed others. Instead of decreasing and vanishing, the more brutal the Roman emperors struggled to annihilate them, Christians slowly and steadily became more and more. This changed when emperors Galerius (311 AD in the east) and Constantine (313 AD in the west) legalized Christianity, perhaps intending to integrate and marginalize it in the multifaceted fabric of numerous different cults in the Empire. But in the same century already, under Theodosius (379-394 AD), Christianity was declared the official cult of the Empire, pagan temples were closed and then destroyed, and step by step the so called pagan religions were totally annihilated. In fact, wherever Christians gained power throughout the Middle Ages and in the early Modern Era, all other religions were exterminated. Christianity would not be the largest world religion today, had not Latin America, where most Christians live today, been Christianized: with Bible and sword, through merciless exploitation and even genocide. On the other hand, most Muslims today live in southeastern Asia (foremost Indonesia), where no Muslim armies ever reached. Under Muslim rule were the Christian and Jewish religions, as a rule (not without exceptions though), tolerated, even the construction of churches and synagogues was sometimes co-financed by the sultans of the Ottoman Empire. For instance in Sarajevo, mosques, churches and synagogues were erected in their reciprocal vicinities. At the same time, Christian Europeans combatted each other and enforced settlements for what is being called "peace between religions": in each territory the population had to accept the denomination (either Catholic or Protestant) of their ruler, or were expelled. Far more victims were created by the Thirty Years' War (1618-1648 AD), fought among Christians for their political power claims in Central Europe, than by the Ottoman wars against them in the $16^{\text {th }}$ and $17^{\text {th }}$ centuries.

Challenging our well accustomed patterns of perception may help to realize that the Church, as an institution, was very far away from how today Christians predominantly understand their religion - as long as it wielded political power. Islam, or Muslims, on the other hand, appear to have managed much better to cope with power, even though the examples of the past do not catch up on modern concepts of equal rights and freedom, and cannot serve as a model for the present or the future. Famous Al-Andalus is frequently 


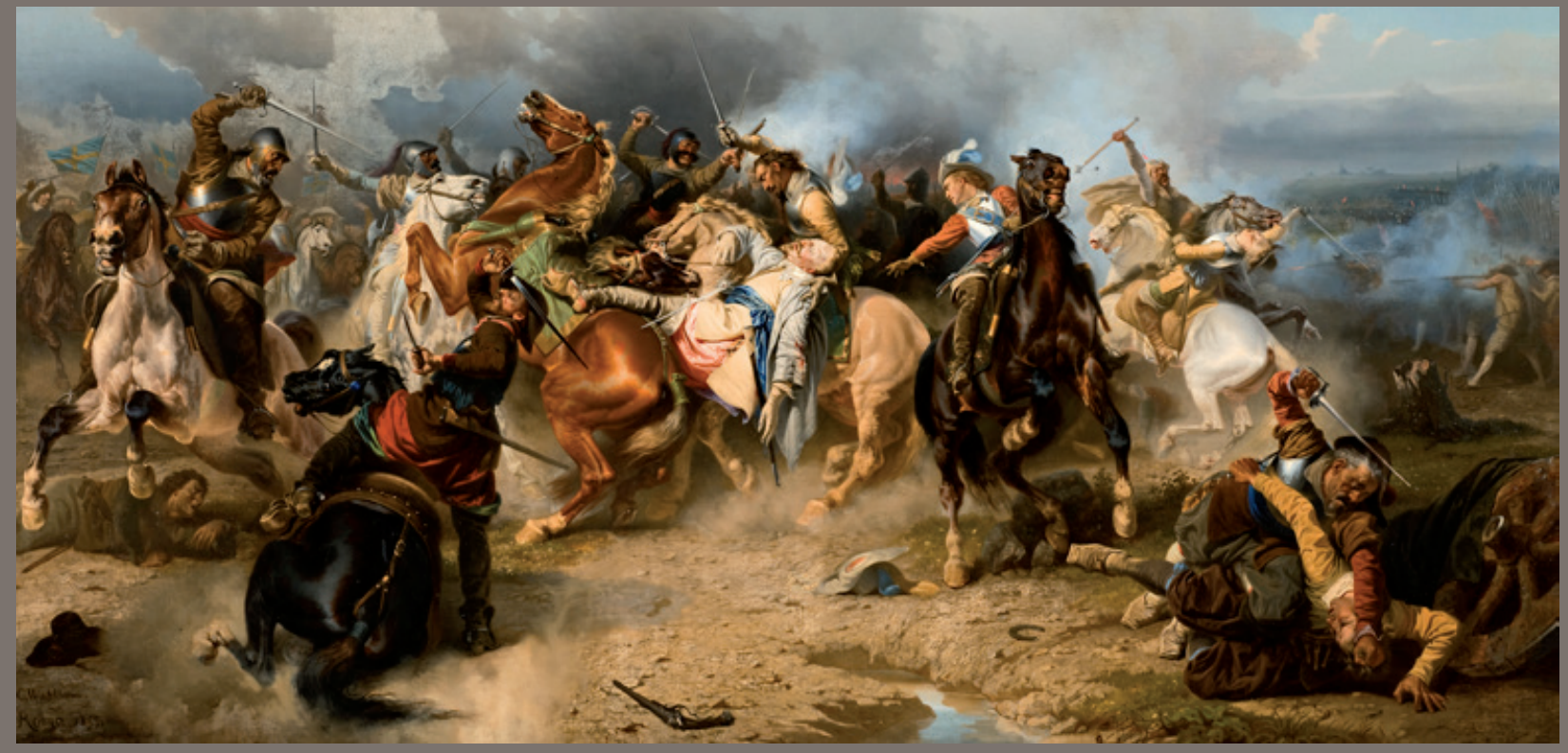

ILLUSTRATION Thirty Years' War - the moment when the Swedish King Gustav II Adolf is killed on the battlefield at Lützen on 6 November, 1632. ILUSTRACIJA Tridesetogodišnji rat - momenat kada je švedski kralj Gustav II. Adolf ubijen na bojnom polju u Lützenu 6. novembra 1632.

mentioned in this respect. From the Christian-European point of view it appears like an illustrious and exceptional episode, but in the context of Muslim societies it was not that peculiar, given that comparable conditions were frequent in the Islamic past.

As a consequence, we have to disrupt our comfortable schemes of thinking, and revise the notion, so wide spread in the West, of Islam as a militant religion as opposed to Christian love for the neighbor (and, of course, the other way round as well). I shall not specify, therefore, in the following, what either Christianity, or Islam may imply for a secular society. Of concern is religion as such.

\section{Enlightenment}

$t$ this point, some would raise an objection, which is very frequent in the West. Hardly any discussion on islam among non-Muslims happens without someone pointing out that Muslims bypassed the era of Enlightenment, and we, in our best intentions, would strongly recommend them to catch up and follow, as quickly as possible, in the track of the last two to three centuries of enlightened, Western development. Some are not even aware of the unbearable measure of Eurocentric arrogance that they display. In the Occident, the "Dark Middle Ages" preceded the Enlightenment, followed by the totalitarian power claim of a "Holy Inquisition", and by the devastating wars following the Reformation. Muslim countries did not have (and as a 
rule do not until today) an ecclesiastic institution which would have to be ripped off political power. But they did increasingly fall behind, from the early Modern Era on, in economic and cultural matters. The reasons have little to do with religion, and a lot with politics. The Ottoman fleet was deprived of its maritime supremacy in the Mediterranean in the $16^{\text {th }}$ century by the so called "Holy Alliance", the combined forces of the mercantile Republic of Venice, Catholic Spain, the Knights Order of Malta, and the Papal States. Spain went on and turned the "reconquista", the liberation (from their perspective) of the whole Iberian Peninsula from Muslim rule (accomplished in 1492 AD), directly into the "conquista" - the conquest of the New World (starting in 1492 AD). The unimaginable amounts of gold, which were plundered there, bestowed upon the Christian parts of Europe an unparalleled economic boom, to which the priceless golden décors of our Baroque churches still bear witness. The Muslim regions in Southeastern Europe, Northern Africa, the Middle East, and Central Asia were left behind, and in a literal sense bypassed, when the sea route to India and China around Africa was discovered. The age-old world economic artery known as the Silk Road became obsolete in short time, and in a way most of the former centres of Islamic civilizations became so, too, in the eyes of a "modern world".

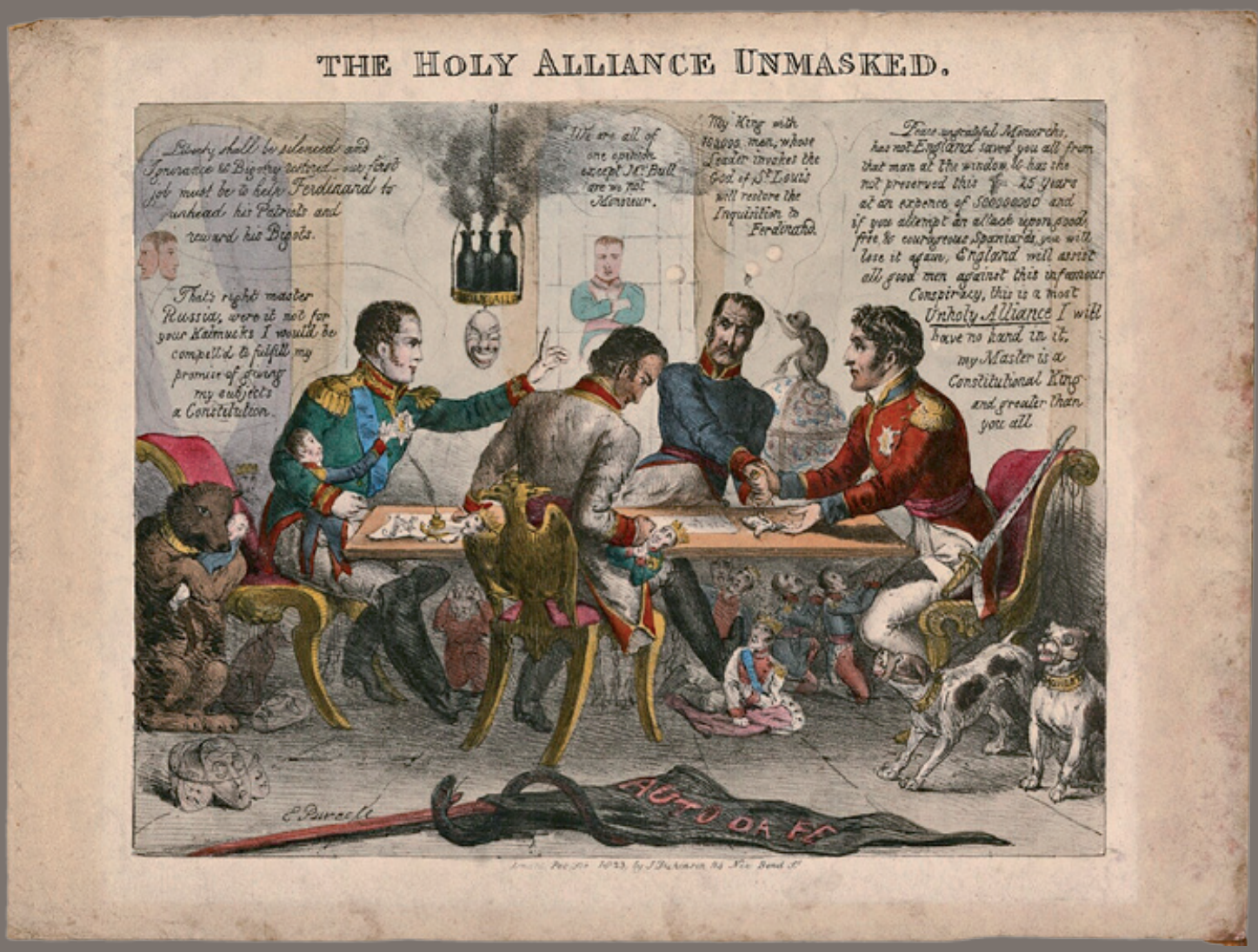

ILLUSTRATION Edward Purcell, The Holy Alliance Unmasked - Alexander I, Tsar of Russia; Napoléon Bonaparte; Francis I, Emperor of Austria; Louis Antoine de Bourbon, duc d'Angoulême; Arthur Wellesley, 1st Duke of Wellington, published February 1823.

ILUSTRACIJA Edward Purcell, Sveti saveznik bez maske - Aleksandar I., car Rusije; Napoléon Bonaparte; Franjo I., austrijski car; Louis Antoine de Bourbon, duc d'Angoulême; Arthur Wellesley, 1. vojvoda od Wellingtona, objavljeno u februaru 1823. 


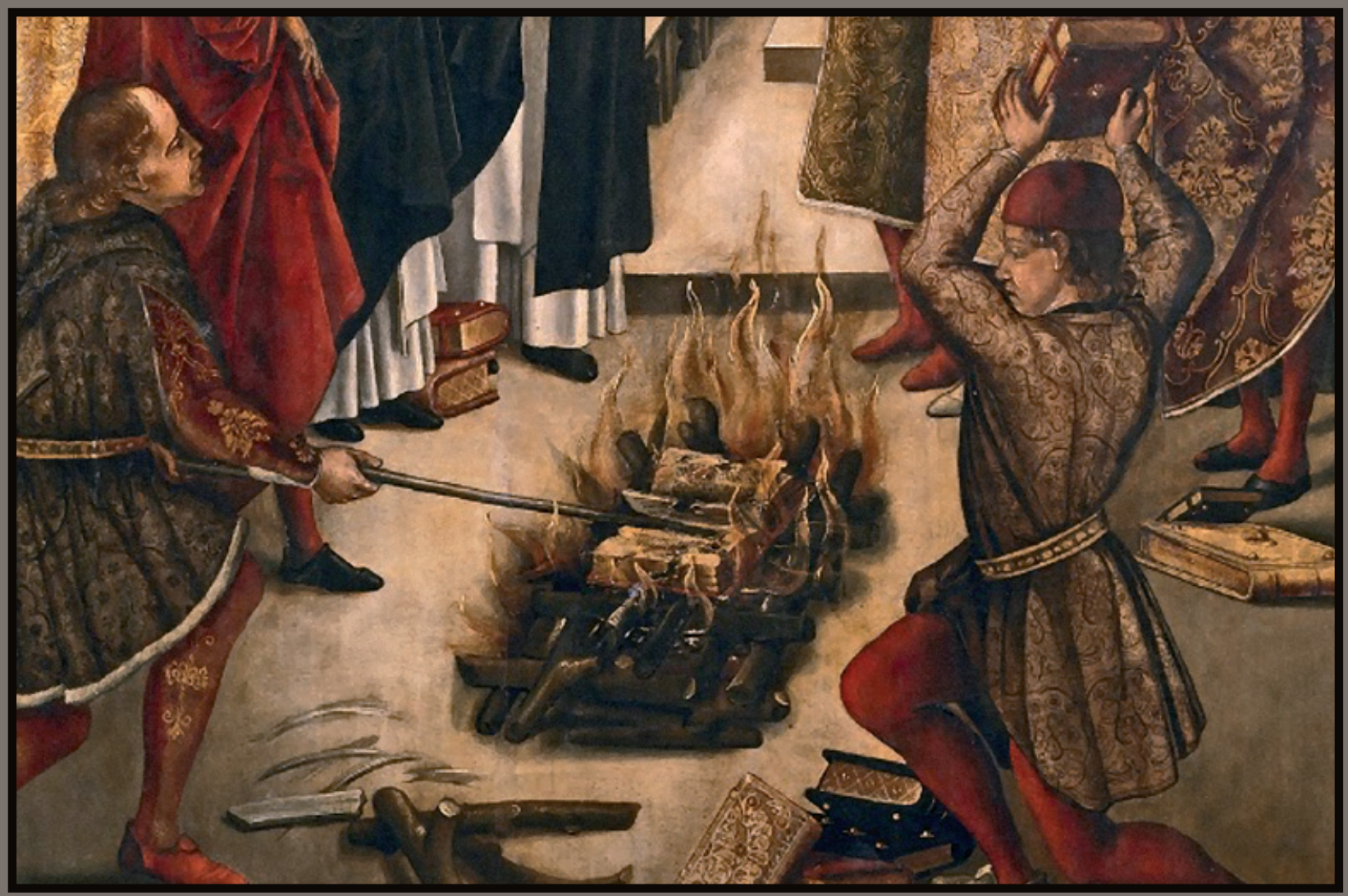

ILLUSTRATION Unknown author, Christian burning of holy books, expulsion of Jews and Muslims from Spain, detail, 1492.

ILUSTRACIJA Nepoznati autor, Kršćansko spaljivanje svetih knjiga, protjerivanje Jevreja i muslimana iz Španije, detalj, 1492.

Simultaneously, in Spain a new concept was shaped and quickly implemented by force: the notion that all must be the same. After the expulsion or compulsory baptism of Jews and Muslims, being Spanish now meant being Catholic. For the first time in world history the chimera of a uniform "nation" in terms of ethnics, language, religion and culture enters the stage (even if the time was premature for the term "nation"). The mania of the absolute, the uniform, and the totalitarian claim to be enforced by violence, marks in fact the transition from the Middle Ages to the Modern Era. The Middle Ages did have their cruelties, but from now on, from the beginning of the $16^{\text {th }}$ century, anything and anyone who would not integrate into the dictated truth, was persecuted much more systematically and with radical and ultimate consistency, than ever before. This new way of thinking, however, cannot be separated from the Enlightenment in Europe, which could not rise without an initially profound hostility against religion, replacing faith with an ultimate claim of rationality and elevating man himself as the absolute.

In the $19^{\text {th }}$ century, nationalism is being developed, first as a movement of masses for their liberation from the powers of absolute sovereigns and aristocracy, before it then degenerates into new dynamite for confrontation and wars, which would surpass by far anything seen before. It was "Christian" Europe, by now 
in fact more and more secular, which exported the monstrosities of nationalism over the world, where they still bedevil the minds of masses.

That is to say, it was not the so called religious wars that lead the world to the edge of the abyss. It was secular ideologies like Fascism, National Socialism, Stalinism (without wanting to equate the different), which generated unimagined dimensions of inhumanity. And the historic world record for barbarism is not held by "holy warriors" of any kind, but by an enlightened and educated, civilized nation in the centre of Europe in the $20^{\text {th }}$ century - by committing the Holocaust.

Today, terror attacks by Da'esh (the diabolic organization that would want us to call them "Islamic State", which is why we should never do so) and many others, do frighten us and want to challenge our civilization. But, put in perspective: It is the wrong and injustice of our modern world economic order, which creates more victims by each second, causes more and more horrible wars, disregards and violates nature and environment, and will inevitably lead, if not stopped, into the destruction of living conditions for mankind on the planet.

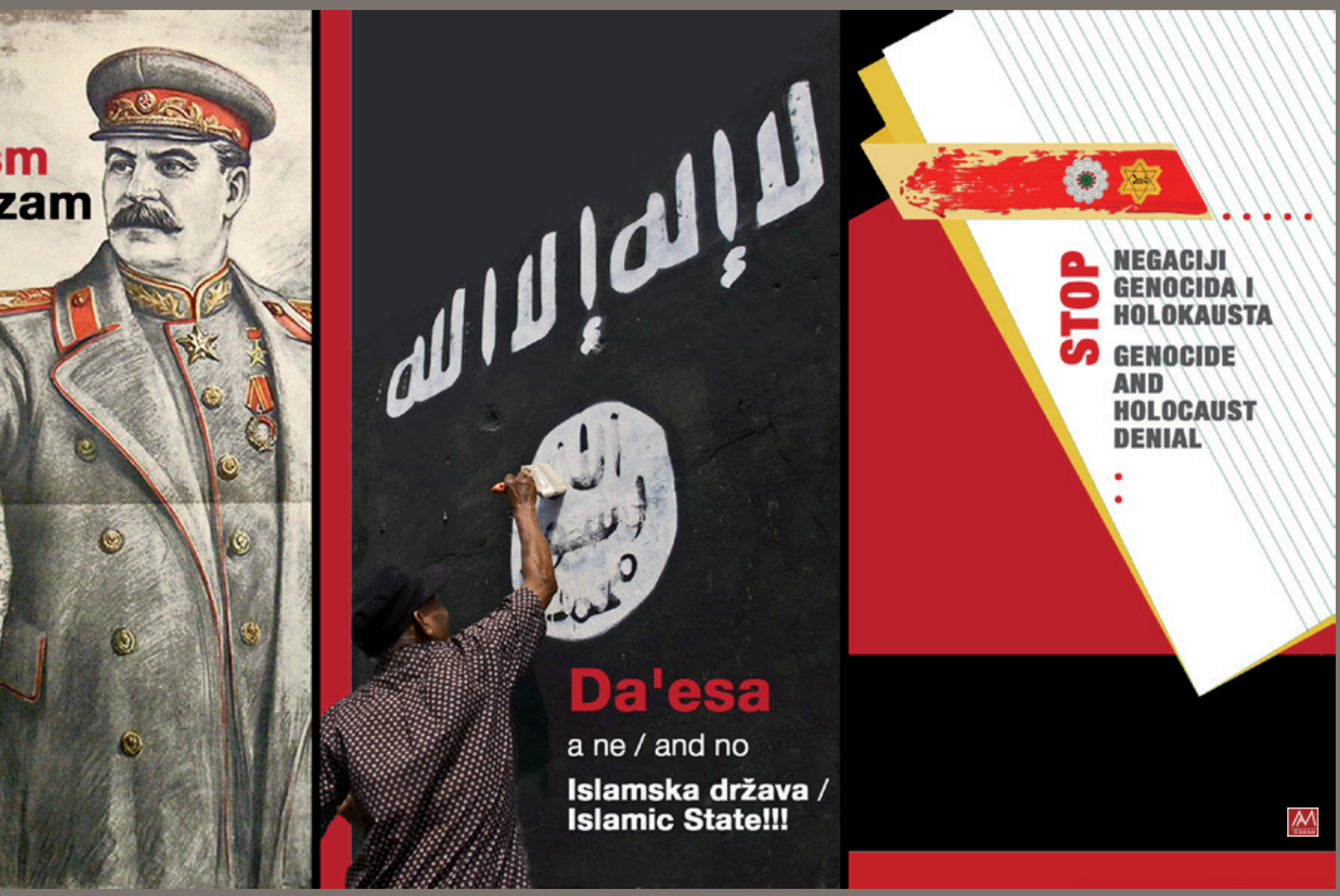

ILLUSTRATION „Holy warriors", in the name of secular ideologies such as fascism, National Socialism, Stalinism, Da'esh terrorist attacks and many other forms that caused the Holocaust and genocide ... 


\section{The present situation}

hese considerations are by no means meant to suggest that we cannot be profoundly grateful for the

achievements of Enlightenment, and for the secular state, which is one of the most precious among them. They have, in the long run, created the conditions we enjoy today: Youth groups, for instance, in church, mosque or synagogue communities, are often interested to learn about other religions, too; they are encouraged to engage for migrants, for democratic values, for gender and social equality, for environmental concerns etc. Here and there these issues are dealt with even more concern (certainly in church communities) than purely religious instruction. In our setting, where considering oneself a religious person is not predetermined by tradition, family or ethnic specifications, and being non-religious is considered "normal" by a mainstream, religion has more to do with engaging oneself for a better world, and not at all, as in the past, with confrontation against others or with competing for power. But it took a lot more than Enlightenment in the 18th century to reach this stage. Two world wars were fought, and the Shoah, the Holocaust, committed, before the church institutions really started to understand and adopt non-violent conflict resolution as their very own mission; before Christians really started to discover and adopt their relational bonds with Jews. And did not the Church display, in parts, much different traits, up until the generations of our grandparents and parents - that were characterized by strictness, rigidity and punishments? The protest movements of 1968 were a decisive factor in most western countries to get the processes underway which led our societies to grant human liberties and adopt responsibilities; these processes are still at work, when different ways of life and gender identities are now respected and gradually being equated. At first glance it may appear hazardous to see a connection - but was it purely coincidental that the 1968 movements were preceded by the Second Vatican Council of the Catholic Church, which lasted from 1962-1965? The Church had for centuries been regarded as almost synonymous with rigidity, immutability and immovability. Observing this institution suddenly accomplishing truely radical changes and achieving wide ranging advancements, opening itself and becoming more "human" in the best sense, must have been momentous in a way that reached out far beyond its own structures.

Some positive dynamics seem to have generated reciprocal corrective factors, in the religious and the secular fields. Neither can develop in isolation from each other; lessons can be learnt from what was going on in the other's sphere, stimulations and impulses are being taken up and developments shape oneself and each other. At least we can say that religious and secular currents need not compete against each other in a confrontative manner.

This may appear optimistic - and that is how it is meant. This can come unexpected, considering the developments around the globe. In more and more countries politicians that openly distort and deny facts, incite against others and elevate their own nations and themselves above others, are being supported and applauded by masses. The global dangers that are threatening us, have been depicted above. So why optimism? 
Because resignation is not part of religion, of no religion. Resignation is the opposite of religion. Religion cannot do without hope, without love and without faith. Religions cannot run out of power, because they are close to the sources. Religions cannot think in a profit-making way, in terms of costs and benefits, and announce: If I invest here, I want to gain an immediate result. Religions are not traded at the stock exchange. They have no upper limits for helping people in need. They do not ask what our economy gains, nor do they care about national pride. Religions do not erect protective walls and fences. As Manfred Görg² out it: "Religion requires open-mindedness." Among the strength of religions is perseverance.

From an atheist point of view, those sources, upon which the religions rely, would be a fata morgana, or possibly an illusion from an agnostic perspective. But on a philosophical track, what we call reality might itself be an illusion. What counts, is in the end the outcome: people in each and every corner of this world, who commit themselves and struggle for a better future, because they have (or believe to have) good reasons not to resign.

We do not need here to pose the question of the existence of God. In cultural anthropology, it is sometimes insinuated that it was fear, in view of man's exposure to the challenges of nature, that motivated the imagination of a "supernatural power" in the early development of mankind. Just as well it could have been the desire for a vis-à-vis, for an addressee, where to direct one's feelings of awe and joy about the world and one's own existence - in other words: gratefulness. We cannot decide these questions. But we can determine that the believe in the divine, in deities, or in God, reflects a desire that is deeply rooted in the etiology of humanity. Without religion, essential questions of the conditio humana are left unanswered. But because reality will always remain unfathomable to us, there is no point in building conflicts between religious and non-religious viewpoints.

\section{What to do?}

a society, just like an individual, depends on a sound balance between stability and dynamics. Both are vital! Stability alone would mean stagnation, petrification. But change needs to be grounded in a sound reference to the present and the past. Religions provide roots and support, and thus they empower people to move on and to grow. Religions - when understood properly - provide stability and demand dynamics as well, in an ideal way. In the introduction to his PhD-thesis, Imam Benjamin Idriz ${ }^{3}$ from Penzberg near Munich, who is among the most prominent Muslim personalities in Germany, makes this point, as far as Islam is concerned: "I have to explain more often what Islam is not, rather than what it is. Mostly this is because of

\footnotetext{
${ }^{2}$ Manfred Görg (1938-2012) was a Catholic theologian, Egyptologist and Ancient Near Eastern scholar. He founded the Friends of Abrahams Society for research on the history of religions and interreligious dialogue in 2001.

${ }^{3}$ Dr. Benjamin Idriz, born in Skopje, North Macedonia, is an Imam and author living in Germany. He is imam of the Islamic Community of Penzberg, a town near Munich, and initiator and president of the Munich Forum for Islam.
} 
some wrong and dogmatic interpretations of Islam and its perception by Muslims themselves. Some take Islam as a faith, in which all questions have already been addressed by earlier scholars, so that Muslims would have to turn themselves towards the past and assume their faith from those scholars. Even though, they lament the present state and call for a better future. They cannot provide any solutions for the future, as this would be nothing than an immersion into the past, in which they do not live and will never live. This is a kind of utopia, something to be compared with searching for water in a dried up well. Instead of searching for a static well, to quench our thirst, we should search for a river, where water is moving by. Islam is like a river: dynamic and flowing. The source of this river is the Quran, which was sent down to man, whom it has commanded to read,

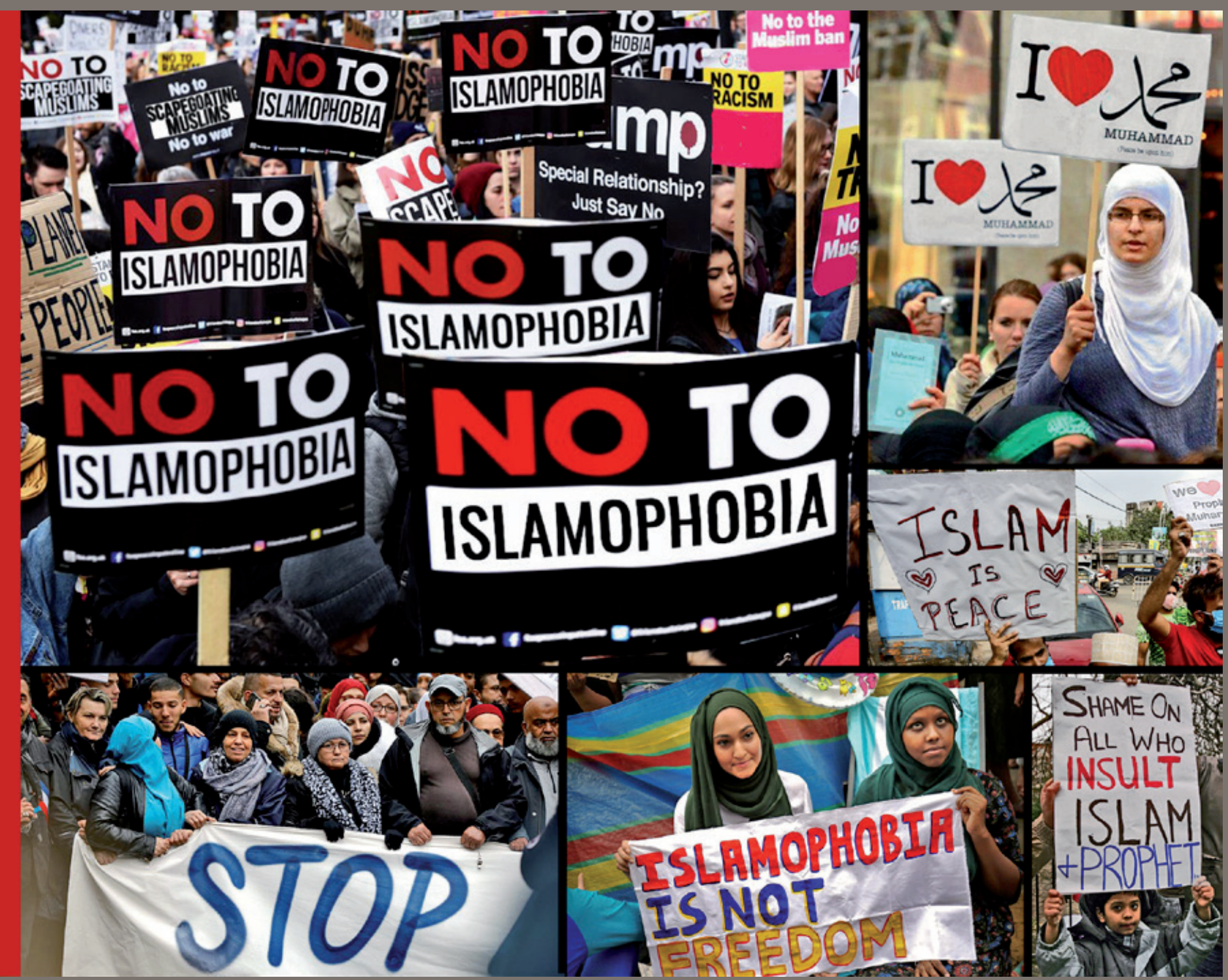

ILLUSTRATION Demonstrations of Muslims against Islamophobia - public and mass voices against Islamophobia.

ILUSTRACIJA Demonstracije muslimana protiv islamofobije - javni i masovni glasovi protiv islamofobije. 
to think, to discuss, to contemplate, to verify, to sense, to work and act in a constructive manner. In the very moment, when the water freezes and stops flowing, the source runs dry and gets useless." ${ }^{{ }_{4}}$

The various manifestations of misuse of religion, which are sadly frequent in today's Muslim world, as we unfortunately must recognize, exemplify how essentially urgent religion needs the secular state. Only a secular state can guarantee the conditions, where there can be no coercion in religion, as the Quran demands (Al-Baqqara 2:256). It can liberate religions from the dangers of stagnation and freezing, and provide a climate for sound progress in accordance with human development. The churches have learnt and understood this fact only as a consequence of the painful processes described above. In turn, the secular state can and should rely upon the religious among its citizens. Instead of suspecting them to constitute an affront against its selfconception, the secular state must comprehend the religious as integral allies. Society benefits, when the religions are comfortable. Just as the religions benefit, when the secular state is comfortable.

Encouraging paradigms for what has been said can amply be found in the statements by the current Pope Francis. In the leftist party in Germany ("Linkspartei") a group of Christians is committed to point out common values and find concerns addressed by the Pope matching some of those promoted by Karl Marx. In his encyclical (a doctrinal letter by the pope to all Catholics) “Laudato si!" (2015), Francis claims that faith cannot be separated from commitment for a just world order, and economy cannot, for believers at least, be separated from ecological concerns. He has promoted environmental issues and climate protection to become key issues of the Church. Sustainability and mindfulness pertaining to God's creation must extend to all His creatures. Neither social justice nor ecological values can be implemented without criticizing the current economic world order. Eventually we will no longer be able to confront the challenges humanity is facing with regard to its future survival on the planet, when the religious and the secular will not pull together and work as one. We can no longer afford religions proceeding each on their own path in self sufficiency and ignorance of others. ${ }^{5}$ Dialogue is a good start, but it must urgently advance into actual team work. Anything else will not guide us to salvation or to God's pleasure, but into aberrance.

This leads us back to the initially outlined, problematic perspectivity of perception. From outside, Francis has been viewed as an exceptional pope, who ostensibly stirs up a lot of what has been considered generic for Catholicism. But in fact, what he has been tackling speaks from the heart of wide sections of the Catholic world, and he is only implementing from above, what ordinary believers have since long been feeling. Quite so, statements by Muslims, such as those by Imam Idriz cited above, are being considered from outside as singular positive votes, against a sea of fundamentalism and backwardness that is perceived and portrayed as "typically Islamic". In reality, it is the extremists and the terrorists, who are marginal phenomena among Muslims - but we yet have to acknowledge this and accordingly adjust our perception.

\footnotetext{
4 "The horizontal aspects in Islam”, PhD-thesis by Benjamin Idriz, in Bosnian language, International University of Novi Pazar 2016.

${ }^{5}$ This in turn is a main concern in the latest encyclical by Pope Francis, "Fratelli tutti” (2020).
} 
What remains to do is questioning our categories of "us" and "others". No longer Christians here as against Muslims there (or vice-versa); and neither religious as against humanists, agnostics, and atheists! Even our accustomed stereotypes of "left" and "right" dilute global and regional challenges rather than contribute to treat them effectively. In point of fact, those who are really confronting each other, are:

those who are committed to living together

contra those who campaign and agitate against,

those who are ready to approach each other in a constructive manner

contra those who oppose each other in a confrontative manner

mutual appreciation

contra mutual disregard, disrespect and contempt of people, and of their values - one's own values and the others' values.

We can find people from the right and from the left, from any religion and without any religion on both sides of this division. Not over questions of secular or religious, but around this battle line the struggle for the survival of mankind is being fought. In order to win it, we must do both:

\section{JOIN THE GOOD SIDE AND ACTIVELY REPEL WHAT IS THREATENING US.}

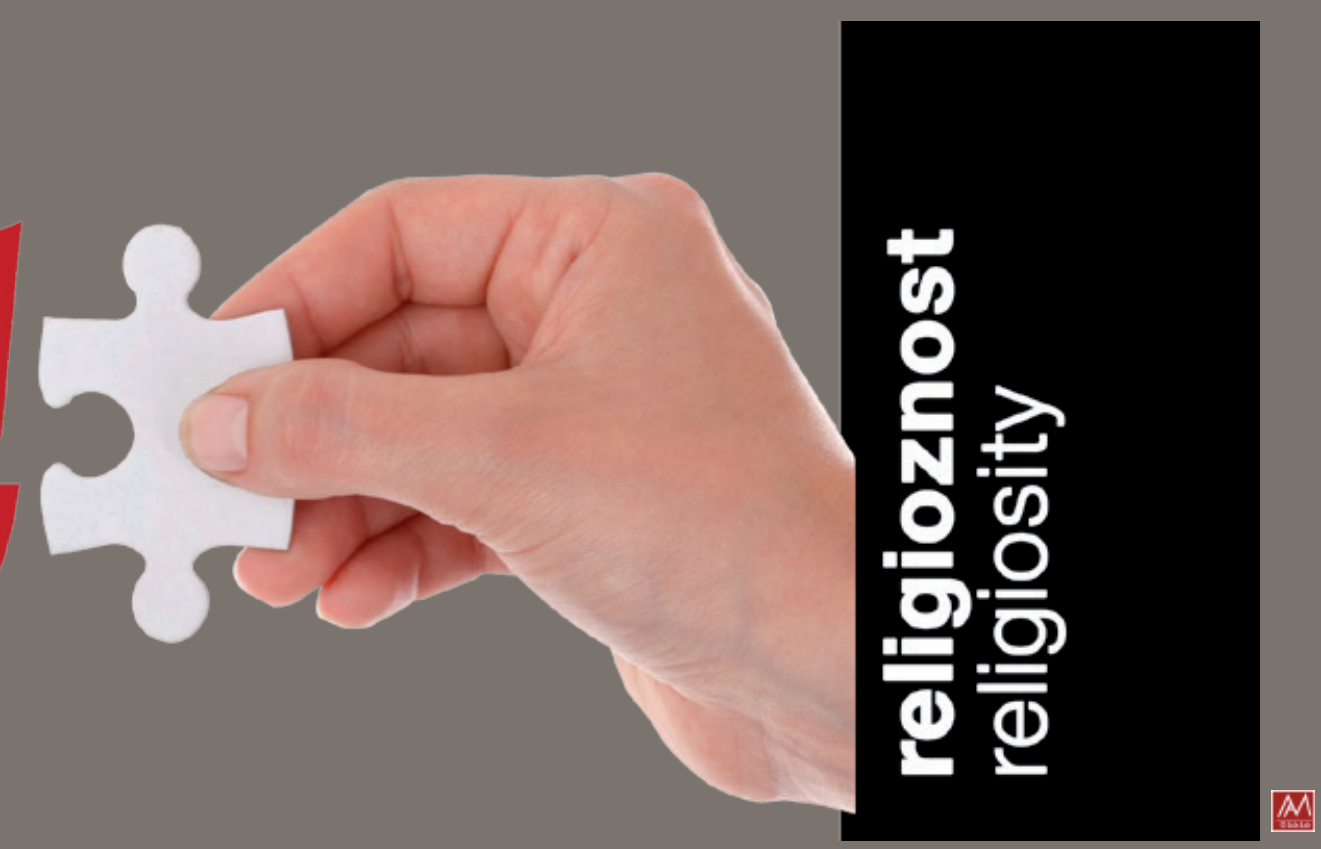

AUTUMN 2020. Volume 2, No. 2. - illuminatio/svietionik/almanar - 239 


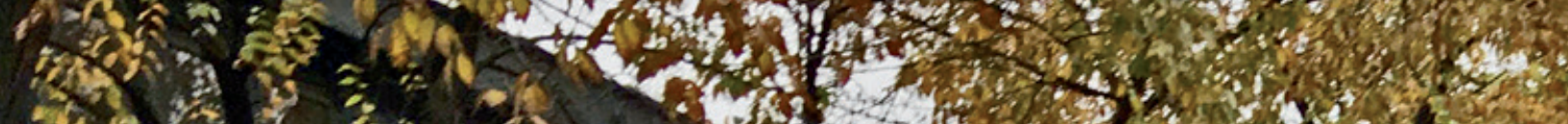

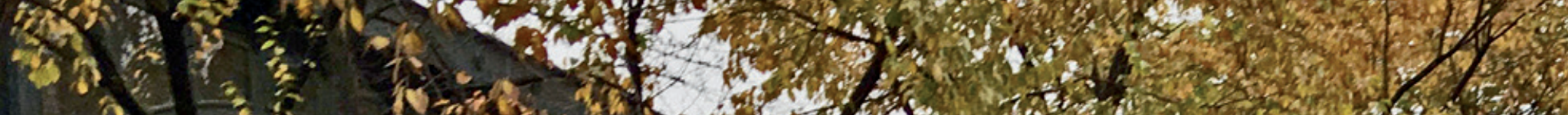

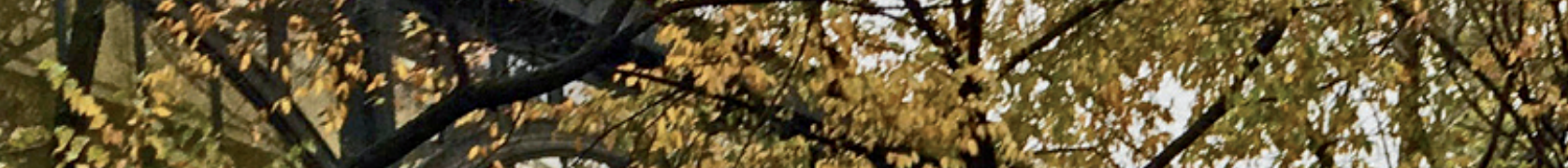

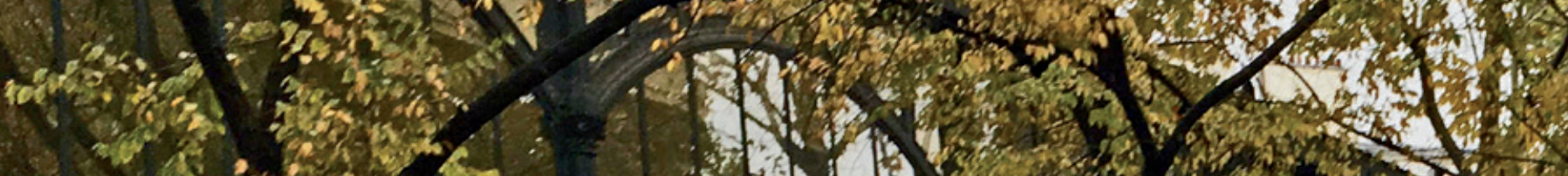

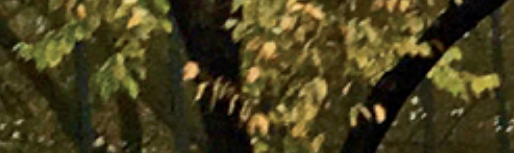

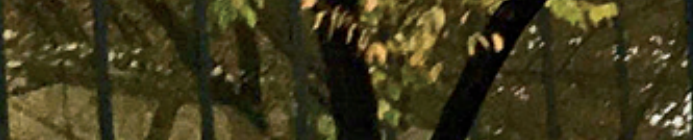

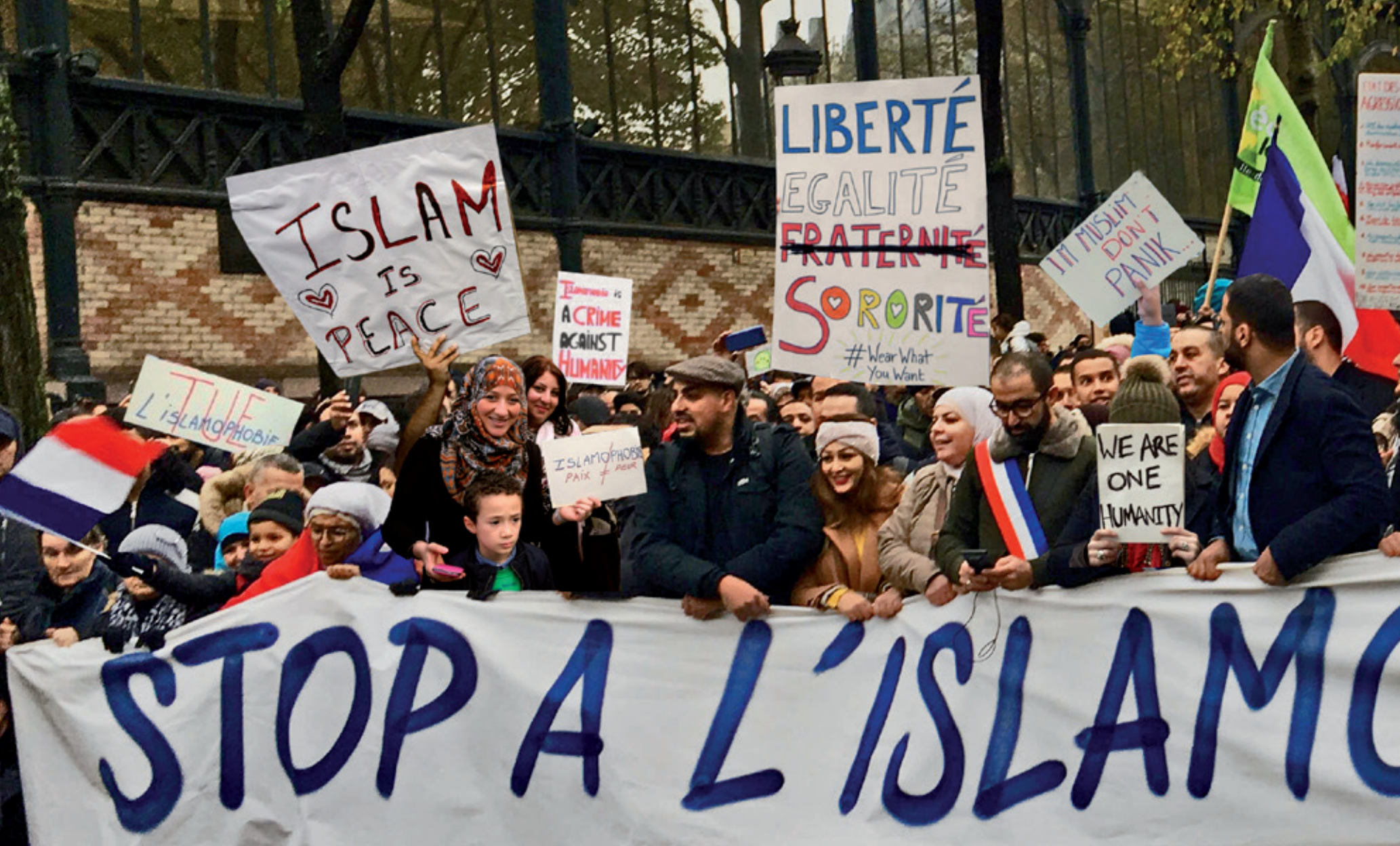

1. - .

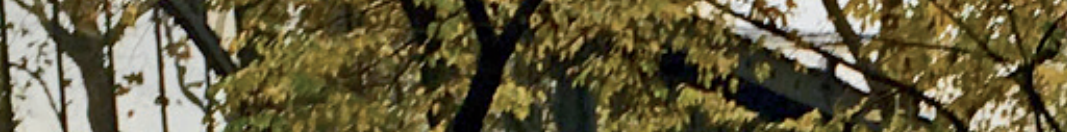

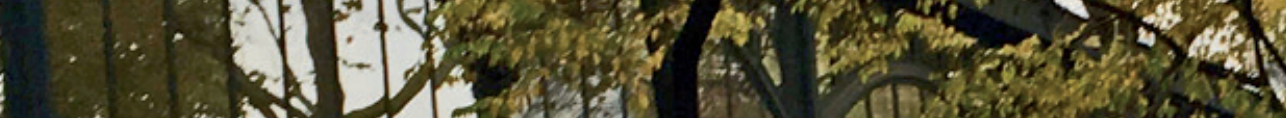

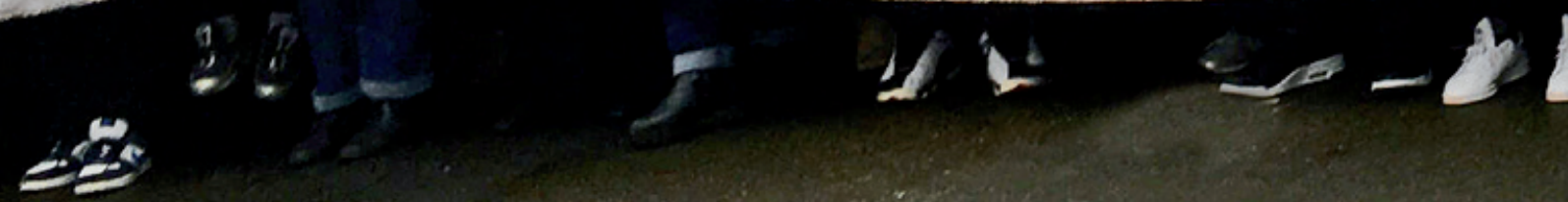


